\title{
新型喹啉-吲哚衍生物的设计、合成及抗肿瘤活性研究
}

\author{
王胜辉 ${ }^{\dagger}, a$ 关永风†, $b$ \\ 刘秀娟 $c$ \\ 原信颖 ${ }^{c}$ \\ 蔚广䂀 $a$ \\ 李银茹 $a$ \\ 张雁冰 ${ }^{c}$ \\ 宋 健*,a,c 李 雯*,b,c \\ 张赛扬*,a,c \\ ( $a$ 郑州大学基础医学院 郑州 450001) \\ ( $b$ 郑州大学化工学院 郑州 450001) \\ ( ${ }^{c}$ 郑州大学药学院 郑州 450001)
}

\begin{abstract}
摘要 作为开发新型有效抗癌药物的进一步工作, 采用分子杂交策略和路易斯酸催化偶联反应设计合成了一系列新型 喹啉-吲哚类化合物. 使用噻唑蓝(MTT)法评估了所合成的化合物对人胃癌细胞(MGC-803)、人食管癌细胞(Kyse450)和 人结肠癌细胞(HCT-116)的体外抑制活性. 其中, 2-氯-4-(5-甲氧基-1 $H$-吲哚-3-基)咺啉(9b)展示较好的体外抗肿瘤活性, 对 MGC-803、Kyse 450 和 HCT-116 三种人源癌细胞 $\mathrm{IC}_{50}$ 值分别为 $0.58,0.60$ 和 $0.68 \mu \mathrm{mol} \cdot \mathrm{L}^{-1}$, 优于阳性对照药 5 -氟尿 嘧啶 $(5-\mathrm{Fu})$ 对这三种肿瘤细胞的抑制活性. 进一步机制研究表明, 化合物 9b 能够剂量依赖地抑制人胃癌细胞 MGC-803 和 HGC-27 的增殖和克隆形成. 化合物 9b 能够诱导人胃癌细胞 MGC- 803 和 HGC-27 内源性调亡和下调相关调亡蛋白 的表达, 并使细胞周期阻滞在 $\mathrm{G} 2 / \mathrm{M}$ 期. 以上结果表明, 化合物 $9 b$ 可以作为先导化合物, 用于进一步研究开发新型高效 抗肿瘤药物.
\end{abstract}

关键词＼cjkstart喹啉; 吲哚; 抗肿瘤活性; 增值; 调亡; 细胞周期阻滞

\section{Design, Synthesis and Anticancer Activity Studies of Novel Quinoline-Indole Derivatives}

\author{
Wang, Shenghui ${ }^{\dagger}, a$ \\ Guan, Yongfeng ${ }^{\dagger, b}$ \\ Liu, Xiujuan ${ }^{c}$ \\ Yuan, Xinying ${ }^{c}$ \\ Yu, Guangxi $i^{a}$ \\ Li, Yinru ${ }^{a}$ \\ Zhang, Yanbing ${ }^{c}$ \\ Song, Jian $*, a, c$ \\ Li, Wen ${ }^{*, b, c}$ \\ Zhang, Saiyang*,a,c \\ ( ${ }^{a}$ School of Basic Medical Sciences, Zhengzhou University, Zhengzhou 450001) \\ ( ${ }^{b}$ School of Chemical Engineering, Zhengzhou University, Zhengzhou 450001) \\ ( ${ }^{c}$ School of Pharmaceutical Sciences, Zhengzhou University, Zhengzhou 450001)
}

\begin{abstract}
As the continuation of our studies on novel and effective anti-cancer agents, a series of novel quinoline-indole derivatives were firstly designed and synthesized by molecular hybridization strategy and Lewis acid-catalyzed coupling reactions. Their antiproliferative potency on gastric cancer cell line MGC-803, colon cancer cell line HCT-116, and esophageal cancer cell line Kyse450 of all the targeted compounds was explored using methyl thiazolyl tetrazolium (MTT) assay. 2-Chloro-4-(5-methoxy-1H-indol-3-yl)quinoline (9b) exhibited potently inhibitory activity against MGC-803, HCT-116, and Kyse 450 cells with $\mathrm{IC}_{50}$ values of $0.58,0.68$ and $0.59 \mu \mathrm{mol} \cdot \mathrm{L}^{-1}$. Further mechanism studies suggested that compound $9 \mathbf{b}$ inhibited the cell colony formation of MGC-803 and HGC-27 cells. Compound 9b induced an intrinsic apoptosis and downregulated the levels of apoptosis related proteins in MGC-803 and HGC-27 cells. Meanwhile, compound 9b arrested MGC-803 and HGC-27 cells at the G2/M phase. Taken together, these results indicated that compound $9 \mathbf{b}$ might be a valuable lead compound for anticancer agents.
\end{abstract}

Keywords quinoline; indole; anticancer activity; proliferation; apoptosis; cell cycle arrest

\footnotetext{
* Corresponding authors. E-mail: mumuangzz@163.com; liwen@zzu.edu.cn; saiyangz@zzu.edu.cn

Received March 30, 2021; revised May 25, 2021; published online June 28, 2021.

Project supported by the National Natural Science Foundation of China (Nos. 81703541, 81673322, U2004123) and the China Postdoctoral Science Foundation (No. 2018M632812).

国家自然科学基金(Nos. 81703541, 81673322, U2004123)和中国博士后科学基金(No. 2018M632812)资助项目.

†共同第一作者(These authors contributed equally to this work).
} 


\section{Introduction}

According to the latest statistics from the International Agency for Research on Cancer (IARC), there were an estimated 19.3 million newly diagnosed cancer patients and almost 10.0 million cancer deaths in 2020. ${ }^{[1]}$ Despite significant advances in cancer treatment and prevention, cancer remains one of the leading causes of death, and successful cancer treatment remains a challenge. ${ }^{[2]}$ Therefore, novel anticancer agents and therapeutic strategies are highly desirable and necessary.

$\mathrm{N}$-Containing heterocycles are extensively used in drug design and discovery. Quinolines are a kind of the six membered nitrogen-containing heterocyclic compounds, and quinoline scaffolds are widely considered as the core skeletons of many natural or synthetic bioactive compounds. ${ }^{[3-5]}$ Quinoline derivatives exbibit a great variety of biological activities, ${ }^{[3-15]}$ such as anticancer, ${ }^{[6]}$ anti-human immunodeficiency virus (HIV) $)^{[7]}$ and anti-inflammation ${ }^{[8]}$ activities. Quinoline-based protein kinase inhibitors such as Anlotinib ${ }^{[9]}$ (multi-kinase inhibitor), Bosutinib ${ }^{[10]}$ (Src-Abl inhibitor) and Lenvatinib ${ }^{[11]}$ (multi-kinase inhibitor) have been approved for clinical application. Quinoline-based hydroxamic acid $\mathbf{1}$ is a dual inhibitor with potent activity against $\mathrm{PI} 3 \mathrm{~K} \alpha$ and $\mathrm{HDAC} 1\left(\mathrm{IC}_{50}=1.3\right.$ and 4.8 $\mathrm{nmol} \cdot \mathrm{L}^{-1}$, respectively). ${ }^{[12]}$ Compound $\mathbf{1}$ also showed attractive antiproliferative potency of A2780 cells with an $\mathrm{IC}_{50}$ value of $2.3 \mu \mathrm{mol} \cdot \mathrm{L}^{-1}$. Quinoline 2 as a tubulin assembly inhibitor displayed potent inhibitory activity against four human cancer cells U87, K562, A549 and HCT-116 with $\mathrm{IC}_{50}$ values $<10 \mathrm{nmol} \cdot \mathrm{L}^{-1}$. [13] Trimethoxyphenyl-quinoline $\mathbf{3}$ is an anticancer agent with inhibitory activity against PC-3 cells $\left(\mathrm{IC}_{50}=9.23 \mu \mathrm{mol} \cdot\right.$ $\left.\mathrm{L}^{-1}\right){ }^{[14]}$ Compound 3 arrested PC-3 cells at the G2/M phase and induced cell apoptosis via activating intrinsic and extrinsic apoptosis pathways (Figure 1). Therefore, we continued with our work on quinoline derivatives to dis- cover potent anticancer agents.

Indoles as one of the most abundant heterocycles among biologically active $\mathrm{N}$-containing heterocycles possess significantly pharmacological effects ${ }^{[16-23]}$ especially anticancer activity. Panobinostat is a novel pan-HDAC inhibitor for the treatment of multiple myeloma. ${ }^{[18]}$ The $3 \mathrm{rd}$ EGFR tyrosine kinase inhibitor Osimertinib was approved for the treatment of non-small-cell lung cancer. ${ }^{[19]}$ Indole 4 is an anti-gastric cancer agent via inhibiting the NEDDylation and MAPK pathways and exhibit attractive inhibitory activity on $\mathrm{MGC}-803$ cells $\left(\mathrm{IC}_{50}=1.59 \mu \mathrm{mol} \cdot \mathrm{L}^{-1}\right){ }^{[20]}$ Quinoline-indole derivative 5, as an anti-tubulin agent targeting the colchicine binding site, shows potently inhibitory potency on tested cancer cell lines with $\mathrm{IC}_{50}$ values ranging from $2 \mathrm{nmol} \cdot \mathrm{L}^{-1}$ to $11 \mathrm{nmol} \cdot \mathrm{L}^{-1}$. ${ }^{[21]}$ 4-Indolyl coumarin $6^{[22]}$ was synthesized by palladium-catalyzed coupling reactions and exhibited significant antiproliferative activity against $\mathrm{MCF}-7$ cells $\left(\mathrm{IC}_{50}=1.42 \mu \mathrm{mol} \cdot \mathrm{L}^{-1}\right)$ (Figure 2). Therefore, in this work, we pay our attention on indole derivatives as anticancer agents.

In this work, as the continuation of our studies on anticancer agents, we assumed that linking indole fragment to the quinoline scaffold through the principle of molecular hybridization strategy and Lewis acid-catalyzed coupling reactions could produce novel bioactive molecules with potential anticancer activity. Therefore, a series of quinoline-indole derivatives were designed and synthesized, and their antiproliferative activity against three selected human cancer cells was evaluated in this work (Scheme 1).

\section{Results and discussion}

\subsection{Chemistry}

Liu et al. ${ }^{[24]}$ described that the Lewis acid and 1,2-dimethoxyethane (DME) could facilitate the direct coupling reactions of electron-rich arenes with aryl halides. Thereby, we attempted to synthesize the novel quinoline-indole
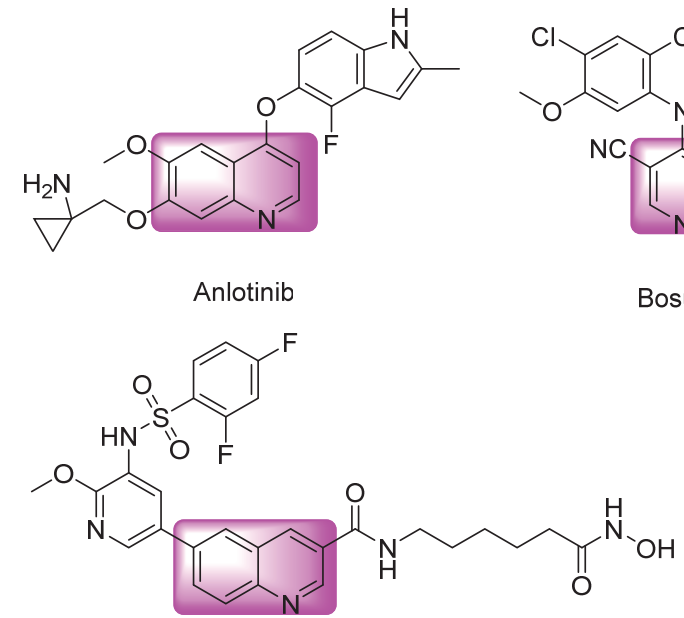

1
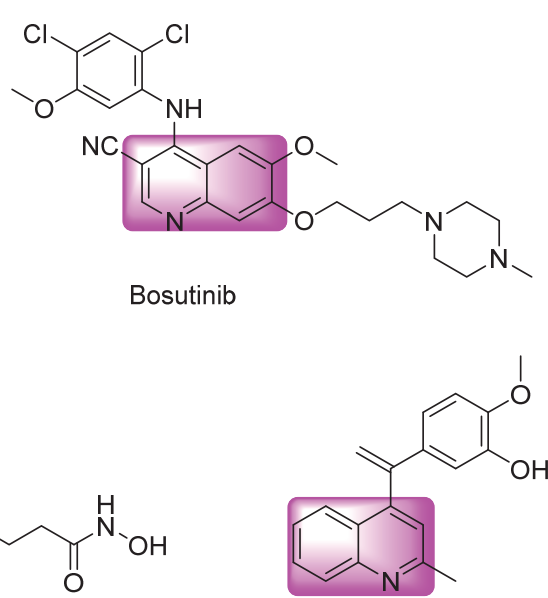

2
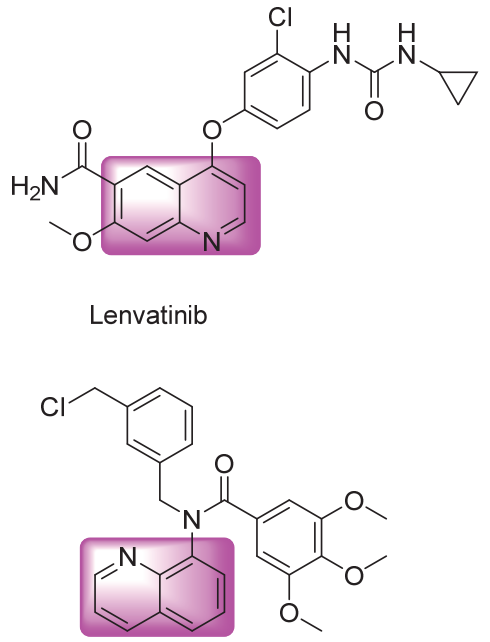

3

Figure 1 Structures of quinoline derivatives as anticancer agents previously reported 

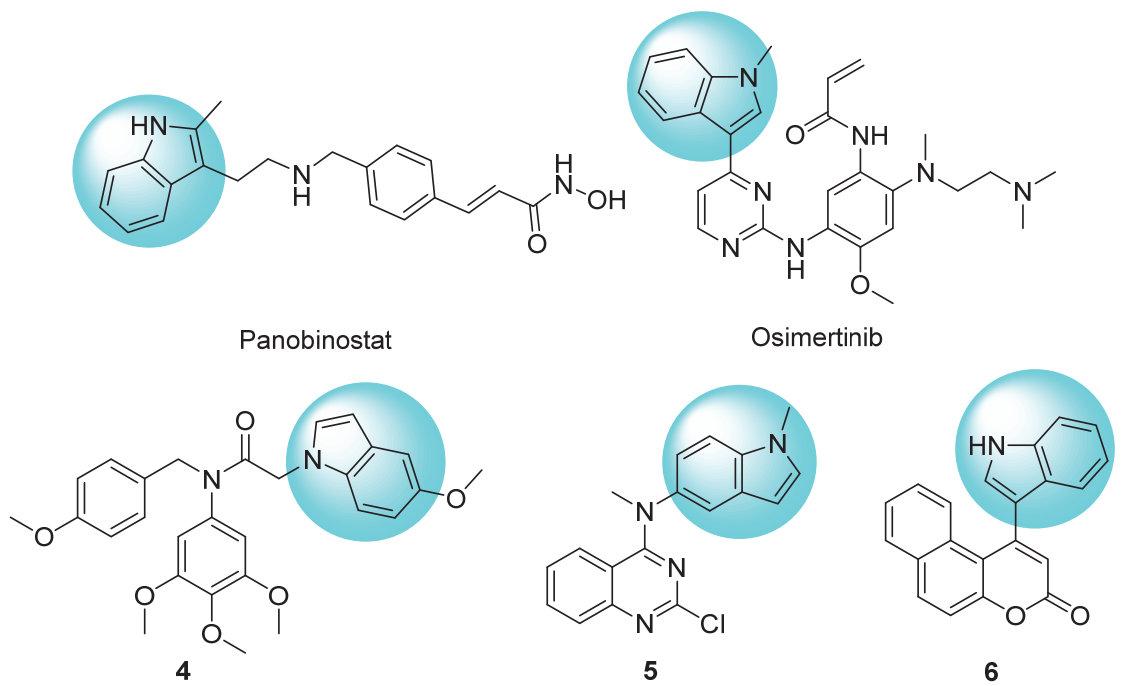

Figure 2 Structures of indole derivatives as anticancer agents previously reported
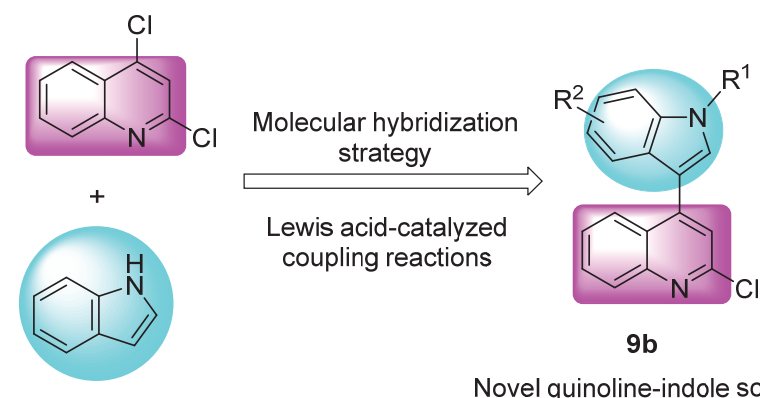

$9 b$

Novel quinoline-indole scaffold Novel anticancer agents

Scheme 1 Design of novel quinoline-indole as anticancer agents via molecular hybridization

derivatives using Lewis acid $\left(\mathrm{AlCl}_{3}\right)$ as the catalyst and DME as the solvent. Fortunately, quinoline-indole derivatives were successfully synthesized by Lewis acid-catalyzed coupling reactions between quinoline and indole scaffolds. As shown in Scheme 2, all the target compounds 9a $\sim 9 j$ were synthesized in one step with commercially available 2,4-dichloroquinoline $\mathbf{7}$ and indoles $\mathbf{8 a} \sim \mathbf{8 j}$ as starting materials. The substitution reactions between 2,4-dichloro-quinoline $\mathbf{7}$ and indoles $\mathbf{8 a} \sim \mathbf{8 j}$ were realized in the presence of $\mathrm{AlCl}_{3}$ in DME at $80{ }^{\circ} \mathrm{C}$, affording quinoline-indole derivatives $\mathbf{9 a} \sim \mathbf{9 j}$ in moderate yields. Characterization of compounds $9 \mathbf{a} \sim \mathbf{9} \mathbf{j}$ was carried out by means of NMR and HRMS spectra.

\subsection{Antiproliferative activity}

Gastrointestinal tumors are common malignant tumors in human body, with high incidence rate and high mortality. The number of new cancers of colorectal cancer, stomach cancer and esophageal cancer ranked second, third and sixth in the number of new cancer cases in China in 2020, respectively. ${ }^{[1]}$ Thus, there is an urgent need to develop effective anticancer agents for the treatment of gastrointestinal tumors. The in vitro antiproliferative activity of new target compounds $\mathbf{9 a} \sim \mathbf{9 j}$ against three human digestive tract cancer cell lines (gastric cancer cell line MGC-803,

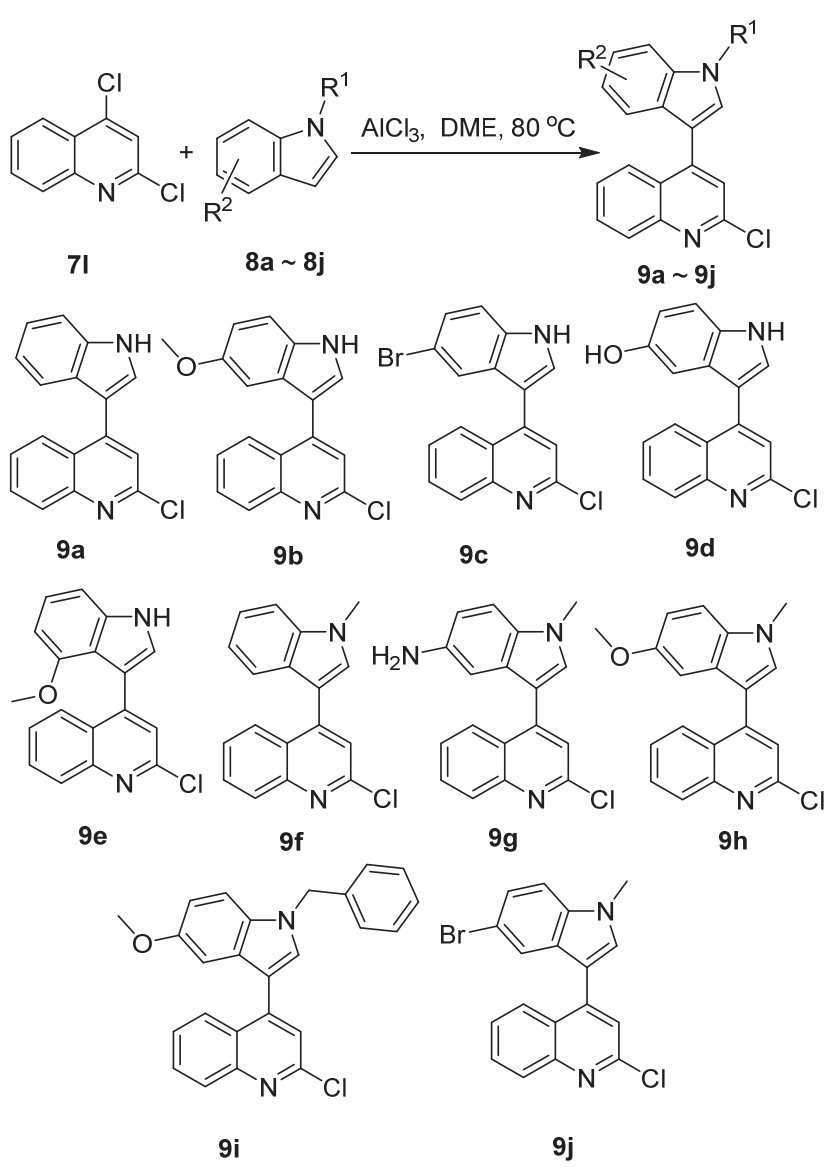

Scheme 2 Synthesis and structures of the target compounds $\mathbf{9 a} \sim 9 \mathbf{j}$

colon cancer cell line HCT-116, and esophageal cancer cell line Kyse450) was evaluated using MTT assay with 5-fluorouracil (5-Fu) as a positive drug. The results of in vitro antiproliferative activity are listed in Table 1.

As shown in Table 1, most of quinoline-indole derivatives exhibited potent antiproliferative potency against five 
Table 1 In vitro antiproliferative activity of compounds $\mathbf{9 a} \sim \mathbf{9 j}$ against MGC-803, HCT-116 and Kyse450 cells

\begin{tabular}{cccc}
\hline \multirow{2}{*}{ Compound } & \multicolumn{3}{c}{$\mathrm{IC}_{50} /\left(\mu \mathrm{mol} \cdot \mathrm{L}^{-1}\right)^{a}$} \\
\cline { 2 - 4 } & MGC-803 & Kyse 450 & $\mathrm{HCT}-116$ \\
\hline 9a & $3.91 \pm 0.22$ & $3.27 \pm 0.18$ & $3.11 \pm 0.16$ \\
9b & $\mathbf{0 . 5 8} \pm \mathbf{0 . 0 1}$ & $\mathbf{0 . 6 8} \pm \mathbf{0 . 0 3}$ & $\mathbf{0 . 5 9} \pm \mathbf{0 . 0 4}$ \\
9c & $4.10 \pm 0.21$ & $5.17 \pm 0.53$ & $8.23 \pm 0.42$ \\
9d & $2.86 \pm 0.19$ & $6.78 \pm 1.04$ & $6.01 \pm 0.37$ \\
9e & $4.34 \pm 0.44$ & $4.68 \pm 0.24$ & $5.91 \pm 0.38$ \\
9f & $7.00 \pm 0.82$ & $5.27 \pm 0.34$ & $11.1 \pm 1.41$ \\
$\mathbf{9 g}$ & $2.42 \pm 0.12$ & $3.04 \pm 0.23$ & $2.87 \pm 0.21$ \\
$\mathbf{9 h}$ & $\mathbf{1 . 1 6} \pm \mathbf{0 . 0 5}$ & $\mathbf{1 . 4 0} \pm \mathbf{0 . 1 2}$ & $\mathbf{1 . 7 1} \pm \mathbf{0 . 1 9}$ \\
$\mathbf{9 i}$ & $>20$ & $>20$ & $>20$ \\
$\mathbf{9 j}$ & $4.58 \pm 0.25$ & $6.57 \pm 0.21$ & $5.06 \pm 0.33$ \\
5-Fu & $6.82 \pm 0.82$ & $17.4 \pm 1.23$ & $14.2 \pm 1.22$ \\
\hline
\end{tabular}

${ }^{a}$ In vitro antiproliferative activity was assayed by exposure for $48 \mathrm{~h}$.

human cancer cell lines with $\mathrm{IC}_{50}$ values $<10 \mu \mathrm{mol} \cdot \mathrm{L}^{-1}$. Particularly, compound 9b exhibited strongest inhibitory activity against MGC-803, HCT-116, and Kyse450 with $\mathrm{IC}_{50}$ values of $0.58,0.68$ and $0.59 \mu \mathrm{mol} \cdot \mathrm{L}^{-1}$, respectively, which were much lower than that of the positive control drug 5-Fu $\left(\mathrm{IC}_{50}=6.82,14.2\right.$ and $17.4 \mu \mathrm{mol} \cdot \mathrm{L}^{-1}$, respectively) and indicated that compound $\mathbf{9 b}$ showed potently inhibitory activity on these three kinds of gastrointestinal tumor cells. The antiproliferative activities of the compounds depended on the substituents of indole group. The position of substituents on indole ring has an important influence on its antiproliferative activity. Compared with compound 9b, compound 9e with the $\mathrm{OCH}_{3}$ substituent at 4-position of indole ring exhibited poor activity than that of compound $9 \mathbf{b}$ with the same substituent at 5-position of indole ring. Most of compounds with the different substituents in the 5-position of indole ring behaved potent antiproliferative activity $\left(\mathrm{IC}_{50}<10 \mu \mathrm{mol} \cdot \mathrm{L}^{-1}\right)$. MGC-803 cells were more sensitive to the compounds than other cancer cells, therefore, the structure-activity relationship of the compounds was discussed based on the antiproliferative activity results of MGC-803 cells. The relationships between the electron-donating groups, electron-withdrawing groups of indole ring and the inhibitory potency against MGC-803 cell lines were $5-\mathrm{OCH}_{3}>5-\mathrm{OH}>5-\mathrm{H}>5-\mathrm{Br}$. The influence of substituents at 2-position of indole ring on antiproliferative activity was also explored. The antiproliferative activity results of compounds $9 \mathbf{9} \sim \mathbf{9 j}$ indicated that the existence of substituents at 1-position of indole ring impaired the inhibitory potency, especially, compound $\mathbf{9 i}$ with a benzyl showed very poor activity against three cancer cells with $\mathrm{IC}_{50}>10 \mu \mathrm{mol} \cdot \mathrm{L}^{-1}$. Based on the above antiproliferative activity results of compounds, we can conclude that directly linking indole fragment to the quinoline scaffold produce novel bioactive molecules with potential anticancer activity. The substituent position of indole ring made a great influence on the inhibitory potency of compounds. Compounds with substituents at 5-position of indole ring exhibited better potency than those with 6-substituent, while compounds with substituents at 1-position of indole ring displayed worse potency than that of compound $\mathbf{9 b}$.

\subsection{Evaluation of biological activity}

\subsubsection{Inhibitory potency of compound $\mathbf{9 b}$ on gastric cancer cells}

For the outstanding antiproliferative activity against gastric cancer cell MGC-803, the inhibitory potency of compound $\mathbf{9 b}$ on another gastric cancer cell line HGC-27 was also investigated. As shown in Figure 3A, compound 9b could inhibit 2 human gastric cancer cells, MGC-803 and HGC-27. The cell viabilities of MGC-803 and HGC-27 cells were decreased significantly in a dose-dependent manner after the treatment with compound $\mathbf{9 b}$ for $72 \mathrm{~h}$. When the concentration of compound $\mathbf{9 b}$ was higher than $500 \mathrm{nmol} / \mathrm{L}$, cell viabilities were reduced over $50 \%$. In the growth curve assay, as shown in Figures $3 \mathrm{~B}$ and $3 \mathrm{C}$, the numbers of MGC-803 and HGC-27 cells in the control group increased more than 4 times than that in the control group after the treatment with compound $9 \mathrm{~b}$ for $72 \mathrm{~h}$. With the effects of high concentration of compound $\mathbf{9 b}$, cell numbers remained unchanged. Cell morphology changes were next to be detected and the images of gastric cancer cells were captured in bright field or after 4,5-diamidino2-phenylindole (DAPI) or Calcein-AM/PI staining. In the growth curve assay, after the treatment with compound $\mathbf{9 b}$ for $48 \mathrm{~h}$, the high concentration of compound $\mathbf{9 b}$ resulted in the concentration and rounding of MGC-803 and HGC27 cells (bright field) and nuclear (DAPI) (Figure 3D). In Calcein-AM/PI staining assay, the cell density is decreased while the dead cells are increased (Figure 3D). These results indicated that compound $\mathbf{9 b}$ evidently inhibited gastric cancer cells.

2.3.2 Detection of cell apoptosis induced by compound $9 \mathrm{~b}$ in gastric cancer cells

The inhibition of compound $\mathbf{9 b}$ against gastric cancer cells may be caused by its effects on cell apoptosis and cell proliferation. The cell apoptosis inducing activity of $\mathbf{9 b}$ was next to be detected. As shown in Figures $4 \mathrm{~A} \sim 4 \mathrm{D}$, compound 9b induced the cell apoptosis of MGC-803 and HGC-27 cells. The apoptosis rates were increased to 73.9\% (MGC-803) and 73.9\% (HGC-27) after the $48 \mathrm{~h}$ high concentration treatments with compound $\mathbf{9 b}$. Levels of cell intrinsic-apoptosis related proteins were then measured, as shown in Figures $4 \mathrm{E} \sim 4 \mathrm{I}$, the levels of proapoptosis proteins Bak, Bax, cleaved-Caspase9 and cleavedPARP were up-regulated, while anti-apoptosis proteins of Mcl-1 and Bcl-xL were down-regulated. These results indicated that compound $\mathbf{9 b}$ induced cell intrinsicapoptosis of gastric cancer cells.

2.3.3 Effect of compound $\mathbf{9 b}$ on cell proliferation of gastric cancer cells

The activity of compound $\mathbf{9 b}$ on cell proliferation against gastric cancer cells was also detected. As shown in Figure 5A, cell colony formatting activity was decreased 

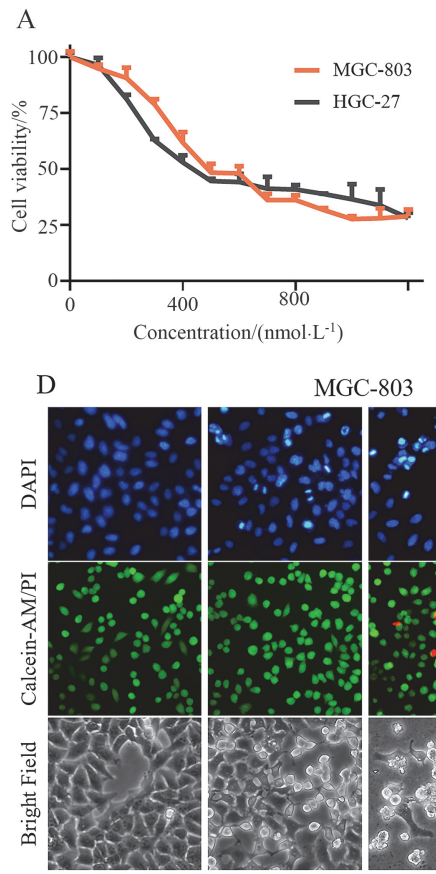

Control

MGC-803

$300 \mathrm{nmol} / \mathrm{L}$
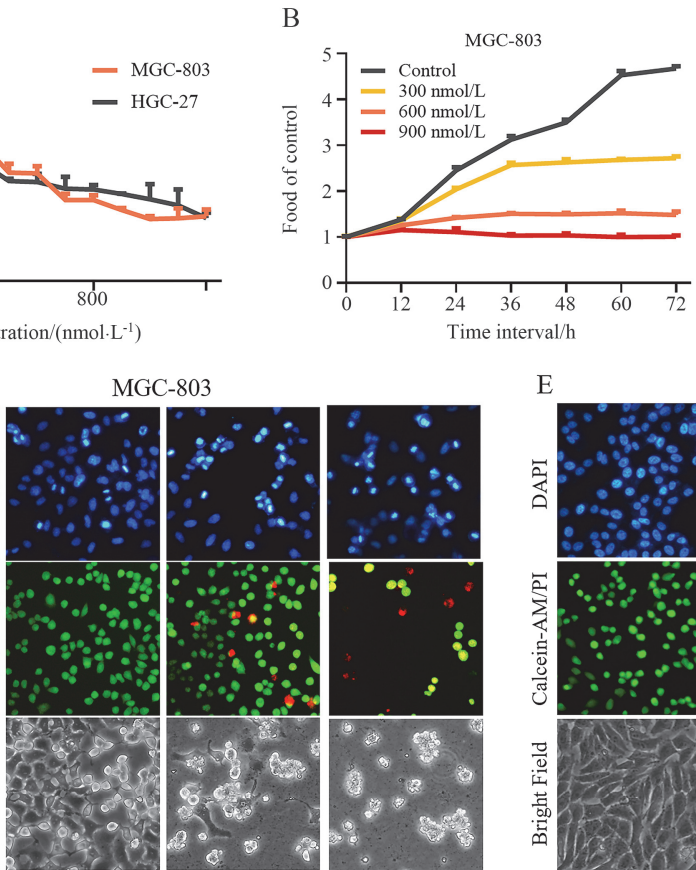

Control

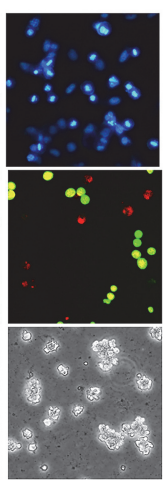

$900 \mathrm{nmol} / \mathrm{L}$

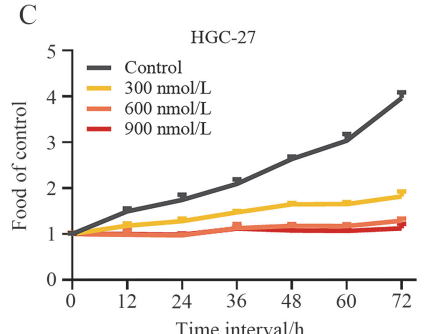

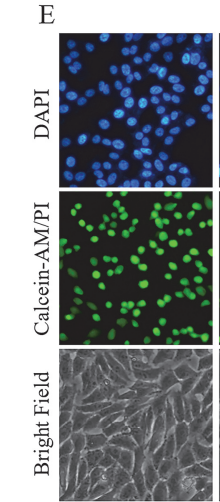

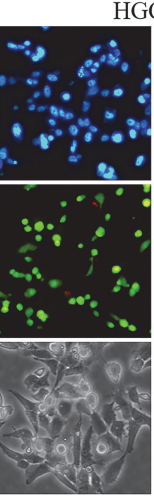

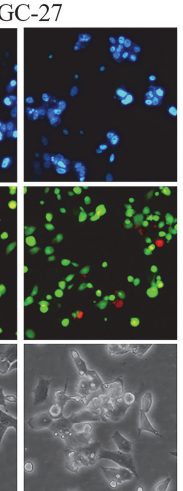

$600 \mathrm{nmol} / \mathrm{L}$

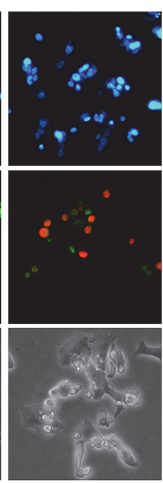

$900 \mathrm{nmol} / \mathrm{L}$

Figure 3 Compound $9 \mathrm{~b}$ inhibited gastric cancer cells in vitro

(A) Cell viability of 2 gastric cancer cells after the treatment with indicated concentrations of $9 \mathbf{b}$ for $48 \mathrm{~h}$; (B, C) Growth curves of gastric cancer cells after the treatment with indicated concentrations of $9 \mathbf{b}$ for $72 \mathrm{~h}$; (D, E) Cell morphology changes. Cells were treated with different concentrations of compound 9b for $48 \mathrm{~h}$, then the images were captured in a bright field or after stained by DAPI or Calcein-AM/PI.

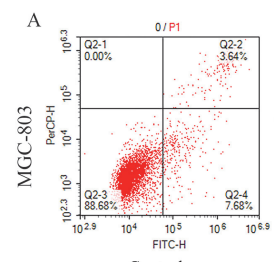

Control

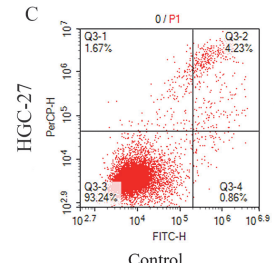

Control

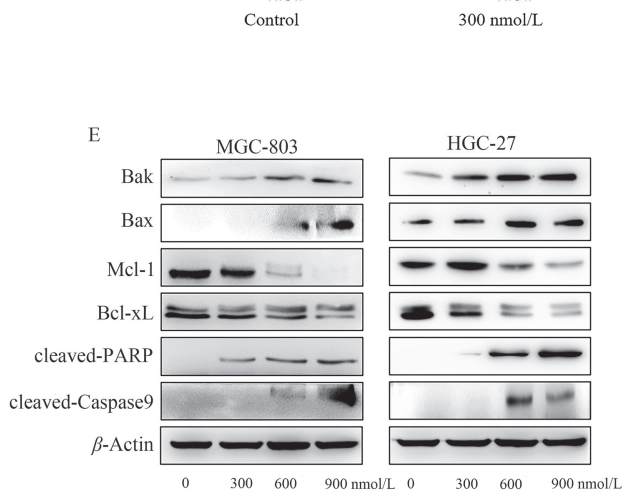

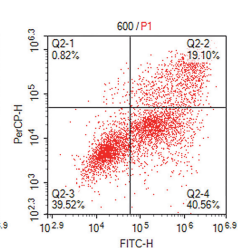

$600 \mathrm{nmol} / \mathrm{L}$
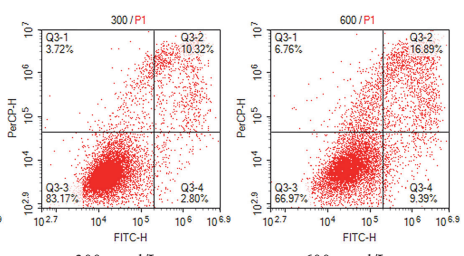

$600 \mathrm{nmol} / \mathrm{L}$

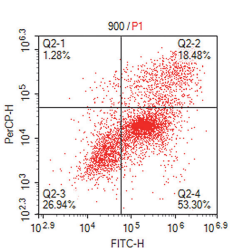

$900 \mathrm{nmol} / \mathrm{L}$

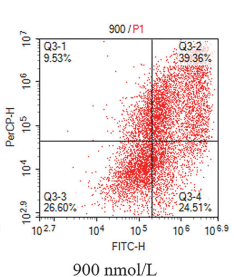

$900 \mathrm{nmol} / \mathrm{L}$
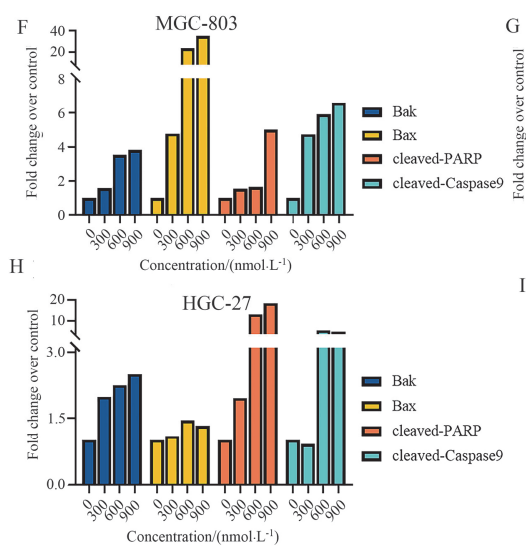

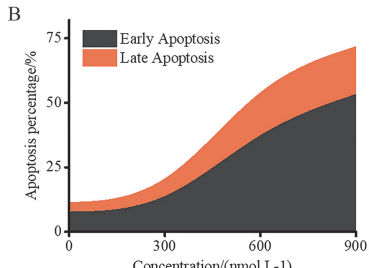

oncentration/(nmol.L-1)

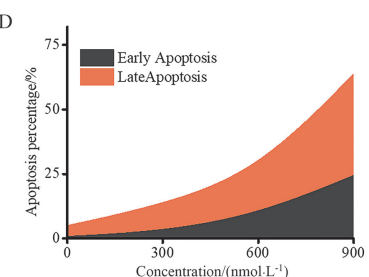

Concentration/(nmol: $\left.\mathrm{L}^{-1}\right)$

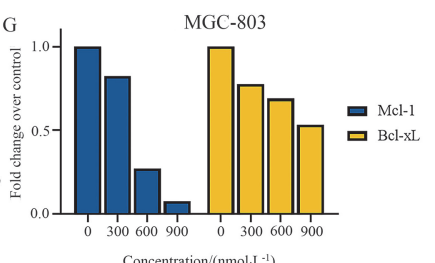

Concentration $/\left(\mathrm{nmol} \cdot \mathrm{L}^{-1}\right)$

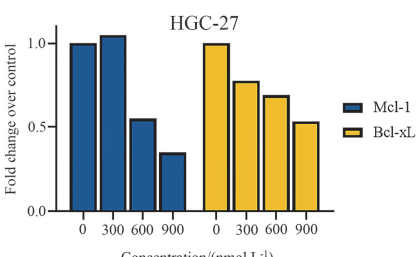

Figure 4 Compound $9 \mathrm{~b}$ induced cell apoptosis

(A $\sim$ D) Cell apoptosis analysis after the treatment with indicated concentrations of compound $\mathbf{9 b}$ for $48 \mathrm{~h}$; (E, F) Levels of intrinsic apoptosis related proteins in 2 gastric cancer cells. Cells were treated with indicated concentrations of compound $\mathbf{9 b}$ for $48 \mathrm{~h}$. 

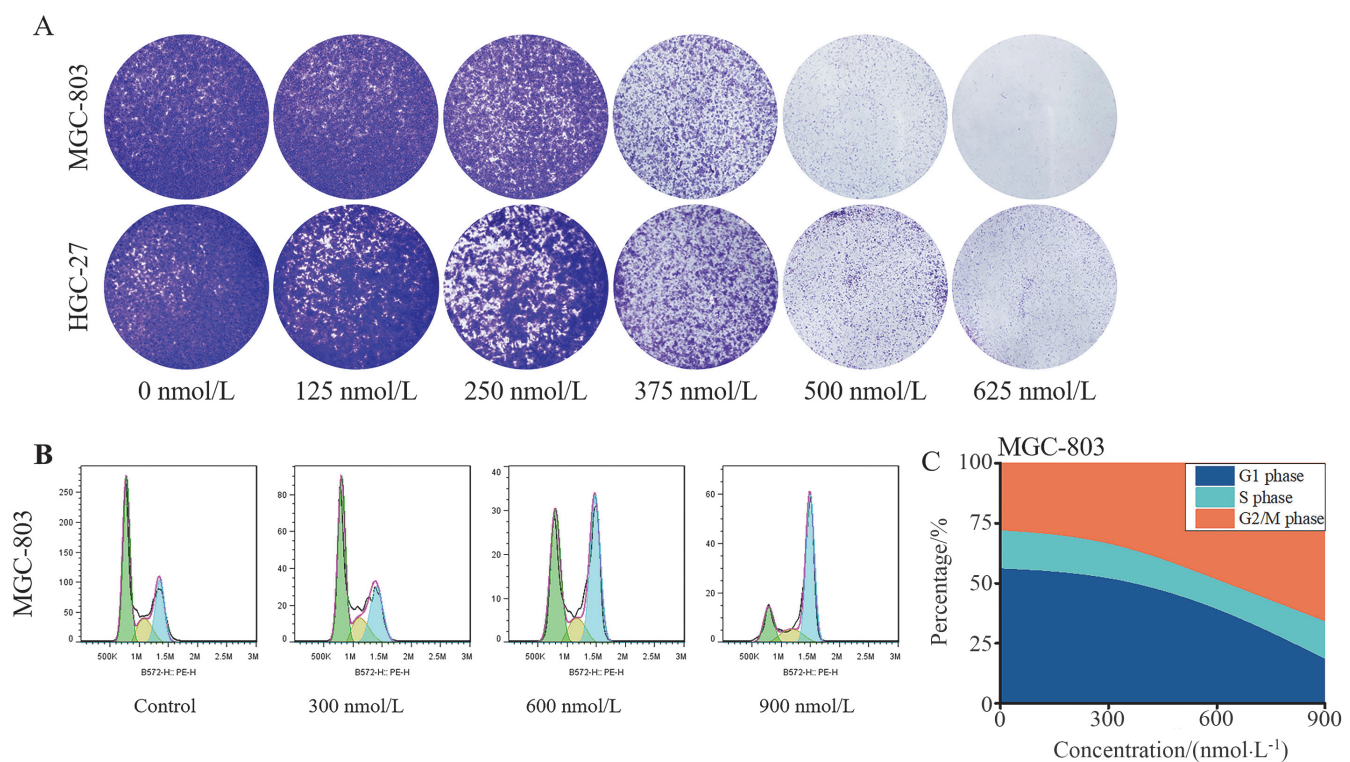

$\mathrm{D}$

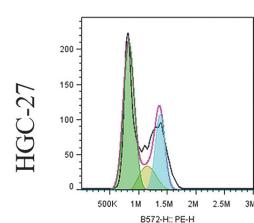

Control

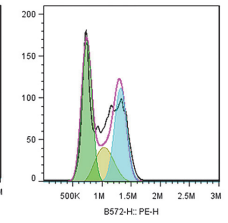

$300 \mathrm{nmol} / \mathrm{L}$

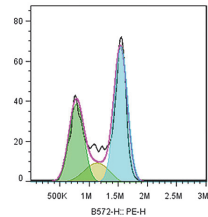

$600 \mathrm{nmol} / \mathrm{L}$

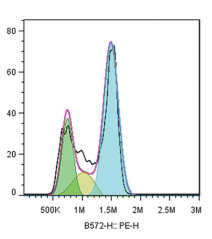

$900 \mathrm{nmol} / \mathrm{L}$

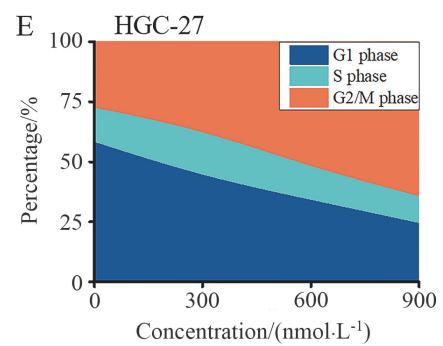

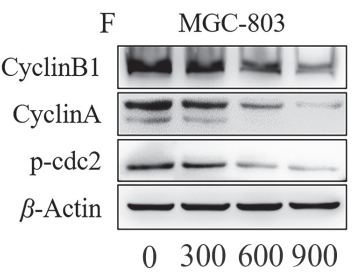

0300600900

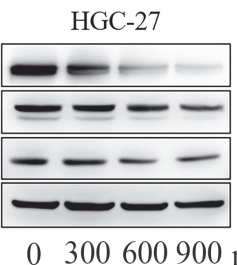

0 $300600900 \mathrm{nmol} / \mathrm{L}$
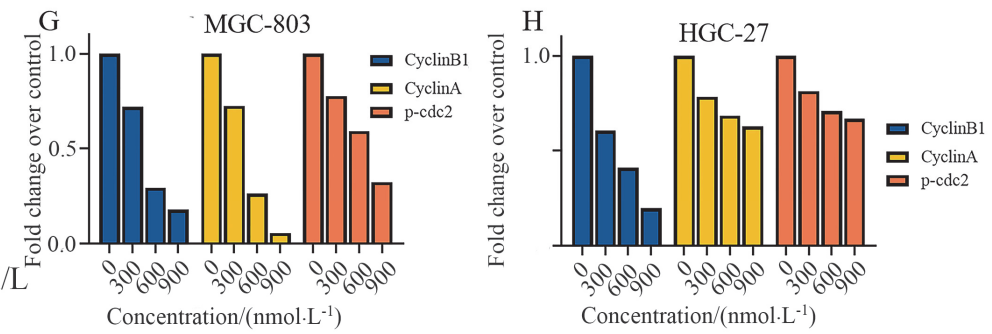

Figure 5 Compound $9 \mathrm{~b}$ inhibited the cell proliferation

(A) Colony formatting analysis, cells were incubated with indicated concentrations of compound $9 \mathbf{b}$ for $7 \mathrm{~d}$; (B $\sim$ E) Cell cycle distribute analysis, cells were treated indicated concentrations of compound $9 \mathbf{b}$ for $48 \mathrm{~h} ;(\mathrm{F} \sim \mathrm{H})$ Cell cycle related proteins in 2 gastric cancer cells. Cells were treated with indicated concentrations of compound $\mathbf{9 b}$ for $48 \mathrm{~h}$.

with a low concentration long term treatment of compound 9b. The orderly progression of the cell cycle is a decisive factor for cell proliferation. As shown in Figures $5 \mathrm{~B} \sim 5 \mathrm{E}$, compound 9b arrested MGC-803 and HGC-27 cells at $\mathrm{G} 2 / \mathrm{M}$ phase. CyclinB, CyclinA1, and $\mathrm{p}-\mathrm{cdc} 2$ are $3 \mathrm{im}-$ portant proteins which promote cell cycle from $\mathrm{G} 2$ to $\mathrm{M}$ phase. The effects of compound $9 \mathbf{i}$ on these proteins were explored in MGC-803 and HGC-27 cells. As shown in Figures $5 \mathrm{~F}$ and $5 \mathrm{G}$, compound $9 \mathrm{~b}$ caused a dose-dependent down-regulation of these proteins. These results indicated that compound 9b inhibited the cell colony formation and arrested gastric cancer cells at G2/M phase.

\section{Conclusion}

In conclusion, a series of novel quinoline-indole derivatives were designed and synthesized by molecular hybridization strategy and Lewis acid-catalyzed coupling reac- tions. All the targeted compounds were characterized by NMR and ESI-MS spectroscopic methods and their antiproliferative activity against MGC-803, HCT-116, and Kyse450 cells was explored using MTT assay. Compound 9b exhibited potently inhibitory activity against MGC-803, HCT-116 and Kyse450 cells with $\mathrm{IC}_{50}$ values of $0.58,0.60$ and $0.68 \mu \mathrm{mol} \cdot \mathrm{L}^{-1}$, respectively. Further mechanism studies suggested that compound 9b inhibited MGC-803 and HGC-27 cells in a dose-dependent manner. Compound 9b inhibited the cell colony formation of MGC-803 and HGC27 cells. Compound 9b down-regulated the levels of apoptosis related proteins and induced an intrinsic apoptosis in MGC-803 and HGC-27 cells. Meanwhile, compound 9b arrested MGC-803 and HGC-27 cells at G2/M phase. Taken together, these results indicated that compound $\mathbf{9 b}$ might be a valuable lead compound for anticancer agents. 


\section{Experimental}

\subsection{Materials}

All the chemical reagents were purchased from commercial suppliers (Energy chemical Company and Zhengzhou He Qi Company). Melting points were determined on an X-5 micromelting apparatus. NMR spectra data was recorded with a Bruker spectrometer. HRMS spectra data was obtained using a Waters Micromass spectrometer.

\subsection{Synthesis of compounds $\mathbf{9 a} \sim \mathbf{9} \mathbf{j}$}

To a solution of substituted quinoline $7(1.0 \mathrm{mmol})$ in DME $(20 \mathrm{~mL})$ at $0{ }^{\circ} \mathrm{C}$ was added $\mathrm{AlCl}_{3}(10 \mathrm{mmol})$. The reaction mixtures were stirred at $25{ }^{\circ} \mathrm{C}$ for $0.5 \mathrm{~h}$, then indoles $\mathbf{8 a} \sim \mathbf{8 j}(3 \mathrm{mmol})$ were added. The resulting solution was stirred at $80{ }^{\circ} \mathrm{C}$ for $5 \mathrm{~h}$. After completion of the reaction [monitored by thin layer chromatography (TLC)], resulting solution was evaporated to give crude products. Crude products were purified by column chromatography (petroleum ether/ethyl acetate, $V: V=4: 1$ ) to give compounds $9 \mathbf{a} \sim 9 \mathbf{j}$.

2-Chloro-4-(1H-indol-3-yl)quinoline (9a): Yellow solid, yield 50\%. m.p. $170 \sim 172{ }^{\circ} \mathrm{C} ;{ }^{1} \mathrm{H}$ NMR $(400 \mathrm{MHz}$, DMSO- $\left.d_{6}\right) \delta: 11.88(\mathrm{~s}, 1 \mathrm{H}), 8.19(\mathrm{~d}, J=7.6 \mathrm{~Hz}, 1 \mathrm{H}), 8.03$ $(\mathrm{d}, J=7.8 \mathrm{~Hz}, 1 \mathrm{H}), 7.91(\mathrm{~d}, J=2.7 \mathrm{~Hz}, 1 \mathrm{H}), 7.85$ (ddd, $J=$ $8.3,6.9,1.3 \mathrm{~Hz}, 1 \mathrm{H}), 7.66 \sim 7.56(\mathrm{~m}, 3 \mathrm{H}), 7.52(\mathrm{~d}, J=8.0$ $\mathrm{Hz}, 1 \mathrm{H}), 7.27 \sim 7.21(\mathrm{~m}, 1 \mathrm{H}), 7.16 \sim 7.10(\mathrm{~m}, 1 \mathrm{H}) ;{ }^{13} \mathrm{C}$ NMR (100 MHz, DMSO- $\left.d_{6}\right) \delta$ : 150.3, 148.6, 146.3, 137.1, $131.2,129.0,127.9,127.4,126.9,126.3,125.9,122.7$, $121.5,120.8,119.4,112.8,111.0$; HRMS calcd for $\mathrm{C}_{17} \mathrm{H}_{11} \mathrm{ClN}_{2}[\mathrm{M}+\mathrm{H}]^{+}$279.0684, found 279.0687 .

2-Chloro-4-(5-methoxy-1H-indol-3-yl)quinoline (9b): Yellow solid, yield 52\%. m.p. $190 \sim 192{ }^{\circ} \mathrm{C}$; ${ }^{1} \mathrm{H}$ NMR $\left(400 \mathrm{MHz}, \mathrm{DMSO}-d_{6}\right) \delta: 11.74(\mathrm{~s}, 1 \mathrm{H}), 8.18(\mathrm{~d}, J=8.3 \mathrm{~Hz}$, $1 \mathrm{H}), 8.02(\mathrm{~d}, J=8.3 \mathrm{~Hz}, 1 \mathrm{H}), 7.89 \sim 7.82(\mathrm{~m}, 2 \mathrm{H}), 7.67 \sim$ $7.59(\mathrm{~m}, 2 \mathrm{H}), 7.47(\mathrm{~d}, J=8.8 \mathrm{~Hz}, 1 \mathrm{H}), 6.95 \sim 6.87(\mathrm{~m}$, 2H), $3.69(\mathrm{~s}, 3 \mathrm{H}) ;{ }^{13} \mathrm{C}$ NMR $\left(100 \mathrm{MHz}, \mathrm{DMSO}-d_{6}\right) \delta$ : $154.7,150.3,148.6,146.5,132.1,131.2,128.9,128.3$, $127.3,127.0,126.7,125.8,121.3,113.5,112.8,110.9$, 101.2, 55.8; HRMS calcd for $\mathrm{C}_{18} \mathrm{H}_{14} \mathrm{ClN}_{2} \mathrm{O}[\mathrm{M}+\mathrm{H}]^{+}$ 309.0789, found 309.0792.

4-(5-Bromo-1H-indol-3-yl)-2-chloroquinoline $\quad$ (9c): White solid, yield 58\%. m.p. 229 $231{ }^{\circ} \mathrm{C} ;{ }^{1} \mathrm{H}$ NMR (400 MHz, DMSO- $\left.d_{6}\right) \delta: 12.06(\mathrm{~s}, 1 \mathrm{H}), 8.11(\mathrm{dd}, J=8.4,1.4$ $\mathrm{Hz}, 1 \mathrm{H}), 8.04$ (d, $J=8.3 \mathrm{~Hz}, 1 \mathrm{H}), 7.96$ (d, $J=2.8 \mathrm{~Hz}, 1 \mathrm{H})$, $7.89 \sim 7.83(\mathrm{~m}, 1 \mathrm{H}), 7.68 \sim 7.61(\mathrm{~m}, 2 \mathrm{H}), 7.60(\mathrm{~s}, 1 \mathrm{H})$, $7.55(\mathrm{~d}, J=8.6 \mathrm{~Hz}, 1 \mathrm{H}), 7.36(\mathrm{dd}, J=8.6,2.0 \mathrm{~Hz}, 1 \mathrm{H}) ;{ }^{13} \mathrm{C}$ NMR (100 MHz, DMSO- $\left.d_{6}\right) \delta: 150.3,148.5,145.5,135.7$, $131.3,129.2$, 129.0, 128.2, 127.6, 126.7, 125.9, 125.2, 121.8, 121.5, 114.8, 113.3, 110.6; HRMS calcd for $\mathrm{C}_{17} \mathrm{H}_{11-}$ $\mathrm{BrClN}_{2}[\mathrm{M}+\mathrm{H}]^{+}$356.9789, found 356.9788.

3-(2-Chloroquinolin-4-yl)-1H-indol-5-ol (9d): Yellow solid, yield 50\%. m.p. 200 203 ${ }^{\circ} \mathrm{C} ;{ }^{1} \mathrm{H}$ NMR (400 MHz, DMSO- $\left.d_{6}\right) \delta: 11.61(\mathrm{~d}, J=2.8 \mathrm{~Hz}, 1 \mathrm{H}), 8.89(\mathrm{~s}, 1 \mathrm{H}), 8.21$ (dd, $J=8.4,1.4 \mathrm{~Hz}, 1 \mathrm{H}), 8.01(\mathrm{dd}, J=8.5,1.3 \mathrm{~Hz}, 1 \mathrm{H})$, 7.84 (ddd, $J=8.4,6.9,1.5 \mathrm{~Hz}, 1 \mathrm{H}), 7.80$ (d, $J=2.8 \mathrm{~Hz}$, $1 \mathrm{H}), 7.68 \sim 7.60(\mathrm{~m}, 1 \mathrm{H}), 7.56(\mathrm{~s}, 1 \mathrm{H}), 7.37(\mathrm{~d}, J=8.7 \mathrm{~Hz}$,
$1 \mathrm{H}), 6.88(\mathrm{~d}, J=2.3 \mathrm{~Hz}, 1 \mathrm{H}), 6.76(\mathrm{dd}, J=8.7,2.3 \mathrm{~Hz}$, $1 \mathrm{H}) ;{ }^{13} \mathrm{C}$ NMR $\left(100 \mathrm{MHz}\right.$, DMSO- $\left.d_{6}\right) \delta: 152.3,150.2$, $148.6,146.7,131.4,131.1,128.9,128.1,127.3,127.1$, $125.7,120.9,113.3,113.1,110.2,103.1$; HRMS calcd for $\mathrm{C}_{17} \mathrm{H}_{12} \mathrm{ClN}_{2} \mathrm{O}[\mathrm{M}+\mathrm{H}]^{+}$295.0633, found 295.0636.

2-Chloro-4-(4-methoxy-1H-indol-3-yl)quinoline (9e): Yellow solid, yield 48\%. m.p. $181 \sim 182{ }^{\circ} \mathrm{C} ;{ }^{1} \mathrm{H}$ NMR $\left(400 \mathrm{MHz}, \mathrm{DMSO}-d_{6}\right) \delta: 11.83 \sim 11.70(\mathrm{~m}, 1 \mathrm{H}), 7.99 \sim$ $7.92(\mathrm{~m}, 2 \mathrm{H}), 7.78(\mathrm{ddd}, J=8.4,6.8,1.4 \mathrm{~Hz}, 1 \mathrm{H}), 7.60(\mathrm{~d}$, $J=2.6 \mathrm{~Hz}, 1 \mathrm{H}), 7.54(\mathrm{ddd}, J=8.3,6.9,1.3 \mathrm{~Hz}, 1 \mathrm{H}), 7.46$ $(\mathrm{s}, 1 \mathrm{H}), 7.16(\mathrm{q}, J=2.9,1.5 \mathrm{~Hz}, 2 \mathrm{H}), 6.59(\mathrm{dd}, J=5.0,3.6$ $\mathrm{Hz}, 1 \mathrm{H}), 3.50$ (s, 3H); ${ }^{13} \mathrm{C}$ NMR (101 MHz, DMSO- $\left.d_{6}\right) \delta$ : $153.8,149.5,147.9,147.6,138.5,130.7,128.3,127.7$, $127.5,126.7,126.4,123.5,122.9,116.5,110.5,105.8$, 101.2, 55.2; HRMS calcd for $\mathrm{C}_{18} \mathrm{H}_{14} \mathrm{ClN}_{2} \mathrm{O}[\mathrm{M}+\mathrm{H}]^{+}$ 309.0789 , found 309.0789 .

2-Chloro-4-(1-methyl-1H-indol-3-yl)quinoline (9f): Yellow solid, yield 48\%. m.p. $145 \sim 147{ }^{\circ} \mathrm{C}$; ${ }^{1} \mathrm{H}$ NMR $\left(400 \mathrm{MHz}, \mathrm{DMSO}-d_{6}\right) \delta$ : $11.97(\mathrm{~s}, 1 \mathrm{H}), 11.14(\mathrm{~s}, 1 \mathrm{H}), 9.11$ (s, 1H), $8.21(\mathrm{dd}, J=6.9,1.4 \mathrm{~Hz}, 1 \mathrm{H}), 7.98(\mathrm{~d}, J=7.8 \mathrm{~Hz}$, $1 \mathrm{H}), 7.77 \sim 7.65(\mathrm{~m}, 2 \mathrm{H}), 7.56(\mathrm{~s}, 1 \mathrm{H}), 7.46 \sim 7.39(\mathrm{~m}$, $1 \mathrm{H}), 7.32$ (t, $J=2.7 \mathrm{~Hz}, 1 \mathrm{H}), 7.11$ (q, $J=8.4 \mathrm{~Hz}, 2 \mathrm{H}), 6.79$ $(\mathrm{s}, 1 \mathrm{H}), 1.92(\mathrm{~s}, 3 \mathrm{H}) ;{ }^{13} \mathrm{C}$ NMR $\left(100 \mathrm{MHz}, \mathrm{DMSO}-d_{6}\right) \delta$ : $150.2,148.6,145.8,137.5,131.9,131.2,129.0,127.5$, $126.8,126.6,125.8,122.8,121.3,121.1,119.5,111.1$, 109.9, 33.4; HRMS calcd for $\mathrm{C}_{18} \mathrm{H}_{14} \mathrm{ClN}_{2}[\mathrm{M}+\mathrm{H}]^{+}$ 293.0840, found 293.0843.

3-(2-Chloroquinolin-4-yl)-1-methyl-1 $H$-indol-5-amine (9g): White solid, yield 55\%. m.p. 158 $160{ }^{\circ} \mathrm{C} ;{ }^{1} \mathrm{H}$ NMR $\left(400 \mathrm{MHz}, \mathrm{DMSO}-d_{6}\right) \delta: 9.36(\mathrm{~s}, 1 \mathrm{H}), 8.28(\mathrm{~s}, 1 \mathrm{H}), 7.94$ $(\mathrm{d}, J=7.7 \mathrm{~Hz}, 1 \mathrm{H}), 7.70(\mathrm{~d}, J=8.0 \mathrm{~Hz}, 1 \mathrm{H}), 7.65(\mathrm{~s}, 1 \mathrm{H})$, $7.44 \sim 7.40(\mathrm{~m}, 2 \mathrm{H}), 7.36(\mathrm{~s}, 1 \mathrm{H}), 7.30(\mathrm{~d}, J=3.0 \mathrm{~Hz}, 1 \mathrm{H})$, $7.22(\mathrm{~s}, 1 \mathrm{H}), 6.42(\mathrm{~d}, J=2.9 \mathrm{~Hz}, 1 \mathrm{H}), 3.79(\mathrm{~s}, 3 \mathrm{H}) ;{ }^{13} \mathrm{C}$ NMR (100 MHz, DMSO- $\left.d_{6}\right) \delta: 155.0,148.7,140.8,133.3$, $133.3,131.1,130.5,128.6,127.0,123.8,123.5,121.4$, $115.9,113.6,111.3,110.1,100.7,33.0$; HRMS calcd for $\mathrm{C}_{18} \mathrm{H}_{15} \mathrm{ClN}_{3}[\mathrm{M}+\mathrm{H}]^{+}$308.0949, found 308.0952.

2-Chloro-4-(5-methoxy-1-methyl-1H-indol-3-yl)quinoline (9h): Yellow solid, yield 53\%. m.p. 155 157 ${ }^{\circ} \mathrm{C} ;{ }^{1} \mathrm{H}$ NMR (400 MHz, DMSO- $\left.d_{6}\right) \delta: 8.20(\mathrm{dd}, J=8.5,1.4 \mathrm{~Hz}$, $1 \mathrm{H}), 8.01(\mathrm{dd}, J=8.5,1.3 \mathrm{~Hz}, 1 \mathrm{H}), 7.88 \sim 7.82(\mathrm{~m}, 2 \mathrm{H})$, 7.63 (ddd, $J=8.3,6.8,1.3 \mathrm{~Hz}, 1 \mathrm{H}), 7.56$ (s, 1H), 7.52 (d, $J=8.8 \mathrm{~Hz}, 1 \mathrm{H}), 7.00 \sim 6.92(\mathrm{~m}, 2 \mathrm{H}), 3.90(\mathrm{~s}, 3 \mathrm{H}), 3.70(\mathrm{~s}$, $3 \mathrm{H}) ;{ }^{13} \mathrm{C}$ NMR (100 MHz, DMSO- $\left.d_{6}\right) \delta: 155.0,150.3$, $148.6,146.0,132.7,132.2,131.2,129.0,127.3,127.0$, $126.9,125.7,121.1,112.7,112.0,109.6,101.4,55.8,33.5$; HRMS calcd for $\mathrm{C}_{19} \mathrm{H}_{16} \mathrm{ClN}_{2} \mathrm{O}[\mathrm{M}+\mathrm{H}]^{+} 323.0946$, found 323.0949.

4-(1-Benzyl-5-methoxy-1H-indol-3-yl)-2-chloroquinoline (9i): Brown solid, yield 50\%. m.p. 142 144 ${ }^{\circ} \mathrm{C} ;{ }^{1} \mathrm{H}$ NMR $\left(400 \mathrm{MHz}, \mathrm{DMSO}-d_{6}\right) \delta: 8.20(\mathrm{dd}, J=8.5,1.4 \mathrm{~Hz}, 1 \mathrm{H})$, 8.07 (s, 1H), 8.03 (dd, $J=8.5,1.3 \mathrm{~Hz}, 1 \mathrm{H}), 7.85$ (ddd, $J=$ $8.4,6.9,1.5 \mathrm{~Hz}, 1 \mathrm{H}), 7.65$ (ddd, $J=8.3,6.8,1.3 \mathrm{~Hz}, 1 \mathrm{H})$, $7.61(\mathrm{~s}, 1 \mathrm{H}), 7.51(\mathrm{~d}, J=9.0 \mathrm{~Hz}, 1 \mathrm{H}), 7.34(\mathrm{~d}, J=5.1 \mathrm{~Hz}$, 4H), 7.27 (ddd, $J=6.5,4.6,3.1 \mathrm{~Hz}, 1 \mathrm{H}), 6.98$ (d, $J=2.4$ $\mathrm{Hz}, 1 \mathrm{H}), 6.89$ (dd, $J=8.9,2.5 \mathrm{~Hz}, 1 \mathrm{H}), 5.54$ (s, 2H), 3.68 $(\mathrm{s}, 3 \mathrm{H}) ;{ }^{13} \mathrm{C}$ NMR (100 MHz, DMSO- $\left.d_{6}\right) \delta: 155.1,150.3$, 
$148.6,145.8,138.2,131.9,131.8,131.3,129.1,129.0$, $128.0,127.7,127.4,126.9,125.7,121.4,112.9,112.5$, 110.3, 101.6, 55.8, 50.1; HRMS calcd for $\mathrm{C}_{25} \mathrm{H}_{20} \mathrm{ClN}_{2} \mathrm{O}$ $[\mathrm{M}+\mathrm{H}]^{+}$399.1259, found 399.1259.

4-(5-Bromo-1-methyl-1H-indol-3-yl)-2-chloroquinoline (9j): White solid, yield 49\%. m.p. 202 203 ${ }^{\circ} \mathrm{C}$; ${ }^{1} \mathrm{H}$ NMR (400 MHz, DMSO- $\left.d_{6}\right) \delta: 8.14(\mathrm{dd}, J=8.5,1.4 \mathrm{~Hz}, 1 \mathrm{H})$, 8.03 (dd, $J=8.4,1.3 \mathrm{~Hz}, 1 \mathrm{H}), 7.97$ (s, 1H), 7.86 (ddd, $J=$ 8.4, 6.9, $1.4 \mathrm{~Hz}, 1 \mathrm{H}), 7.67$ (dd, $J=6.3,1.7 \mathrm{~Hz}, 2 \mathrm{H}), 7.62$ $(\mathrm{d}, J=8.8 \mathrm{~Hz}, 1 \mathrm{H}), 7.57$ (s, 1H), $7.43(\mathrm{dd}, J=8.7,1.9 \mathrm{~Hz}$, $1 \mathrm{H}), 3.95(\mathrm{~s}, 3 \mathrm{H}) ;{ }^{13} \mathrm{C}$ NMR $\left(100 \mathrm{MHz}, \mathrm{DMSO}-d_{6}\right) \delta$ : $150.3,148.5,145.0,136.2,133.2,131.3,129.0,128.3$, 127.6, 126.6, 125.7, 125.3, 121.7, 113.7, 113.3, 109.5, 33.6; HRMS calcd for $\mathrm{C}_{18} \mathrm{H}_{13} \mathrm{BrClN}_{2}[\mathrm{M}+\mathrm{H}]^{+} 370.9945$, found 370.9949 .

\subsection{Cell culture}

Cell lines used were cultured in humidified incubator in a humidified atmosphere of $5 \% \mathrm{CO}_{2}$ and $95 \%$ air. The RPMI-1640 medium was supplemented with $10 \%$ fetal bovine serum, penicillin $(100 \mathrm{U} / \mathrm{mL})$ and streptomycin $(0.1$ $\mathrm{mg} / \mathrm{mL}$ ).

\subsection{MTT assay}

Cell lines were seeded into 96-well plates and incubated for $24 \mathrm{~h}$. Then cells were treated with different concentrations of compounds. And after another $48 \mathrm{~h}$, MTT reagent (20 $\mu \mathrm{L} /$ well) was added to each well and then incubated at $37{ }^{\circ} \mathrm{C}$ for $4 \mathrm{~h}$. After the suspension was discarded, formazan was then dissolved with dimethyl sulfoxide (DMSO). Absorbencies of formazan solution were measured at 490 $\mathrm{nm}$. The $\mathrm{IC}_{50}$ values of tested compounds were calculated by SPSS version 17.0.

\subsection{Western blotting analysis}

2 gastric cancer cells were seeded in dishes and treated with 9b or DMSO. After 48 h, MGC-803 and HGC-27 cells were collected and then lysed. The denatured lysates of each group were electrophoretic separated in sodium dodecyl sulfate sodium dodecyl sulfate-polyacrylamide gel electrophoresis (SDS-PAGE). Proteins were then transferred onto polyvinylidene fluoride (PVDF) membranes from gels. After blocking for $2 \mathrm{~h}$, membranes were incubated with primary antibodies conjugation. Then, the membranes were washed and incubated with $2^{\text {nd }}$ antibodies. At last, specific proteins were detected.

\subsection{General methods}

In this work, some other assays including colony formation assay, cell apoptosis assay and statistical analysis were referred to our previous work. ${ }^{[25]}$

Supporting Information NMR and HRMS spectra of compounds $\mathbf{9 a} \sim 9 \mathbf{j}$. The Supporting Information is available free of charge via the Internet at http://sioc-journal.cn.

\section{References}

[1] Sung, H.; Ferlay, J.; Siegel, R. L.; Laversanne, M.; Soerjomataram,
I.; Jemal, A.; Bray, F. Ca-Cancer J. Clin. 2021, 71, 209.

[2] Boshuizen, J.; Peeper, D. S. Mol. Cell. 2020, 78, 1002.

[3] Matada, B. S.; Pattanashettar, R.; Yernale, N. G. Bioorg. Med. Chem. 2021, 32, 115973.

[4] Yadav, P.; Shah, K. Bioorg. Chem. 2021, 109, 104639.

[5] Afzal, O.; Kumar, S.; Haider, M. R.; Ali, M. R.; Kumar, R.; Jaggi, M.; Bawa, S. Eur. J. Med. Chem. 2015, 97, 871.

[6] Jain, S.; Chandra, V.; Kumar Jain, P.; Pathak, K.; Pathak, D.; Vaidya, A. Arabian J. Chem. 2019, 12, 4920.

[7] Jentsch, N. G.; Hart, A. P.; Hume, J. D.; Sun, J.; McNeely, K. A.; Lama, C.; Pigza, J. A.; Donahue, M. G.; Kessl, J. J. ACS Med. Chem. Lett. 2018, 9, 1007.

[8] Yang, S.-M.; Martinez, N. J.; Yasgar, A.; Danchik, C.; Johansson, C.; Wang, Y.; Baljinnyam, B.; Wang, A. Q.; Xu, X.; Shah, P.; Cheff, D.; Wang, X. S.; Roth, J.; Lal-Nag, M.; Dunford, J. E.; Oppermann, U.; Vasiliou, V.; Simeonov, A.; Jadhav, A.; Maloney, D. J. J. Med. Chem. 2018, 61, 4883.

[9] Zhong, C. C.; Chen, F.; Yang, J. L.; Jia, W. W.; Li, L.; Cheng, C.; Du, F. F.; Zhang, S. P.; Xie, C. Y.; Zhang, N. T.; Olaleye, O. E.; Wang, F. Q.; Xu, F.; Lou, L. G.; Chen, D. Y.; Niu, W.; Li, C. Acta Pharmacol. Sin. 2018, 39, 1048.

[10] Golas, J. M.; Arndt, K.; Etienne, C.; Lucas, J.; Nardin, D.; Gibbons, J.; Frost, P.; Ye, F.; Boschelli, D. H.; Boschelli, F. Cancer Res. 2003, 63, 375.

[11] Glen, H.; Mason, S.; Patel, H.; Macleod, K.; Brunton, V. G. BMC Cancer 2011, 11, 309.

[12] Gu, Y.-Y.; Lv, X.-Q.; Ma, X.-D.; Zhang, H.-J.; Ji, Y.-Y.; Ding, W.-Q.; Shen, L. Chin. J. Org. Chem. 2020, 40, 95 (in Chinese). (顾依钰, 吕晓庆, 马晓东, 张浩健, 嵇媛媛, 丁婉婧, 沈立, 有 机化学, 2020, 40,95.)

[13] Khelifi, I.; Naret, T.; Renko, D.; Hamze, A.; Alami, M. Eur. J. Med. Chem. 2017, 127, 1025.

[14] Wu, B.-W.; Cui, X.-X.; Zhu, T.; Wang, S.-H.; Lu, C.-F.; Wang, J.-J.; Dang, H.-X.; Zhang, S.-Y.; Ding, L.-N.; Jin, C.-Y. Chin. J. Org. Chem. 2020, 40, 978 (in Chinese).

(吴博文，崔金金金，朱挺，王胜辉，陆超凡，王金杰，党贺祥，张 赛扬, 丁丽娜, 金成允, 有机化学, 2020, 40, 978.)

[15] Zhang, D.-Q.; Liu, X.; Pang, X.-J.; Liu, H.-M.; Zhang, Q.-R. Chin. J. Org. Chem. 2020, 41, 267 (in Chinese).

(张丹青, 柳旭, 庞晓静, 刘宏民, 张秋荣, 有机化学, 2020, 41, 267.)

[16] Han, Y.; Dong, W.; Guo, Q.; Li, X.; Huang, L. Eur. J. Med. Chem. 2020, 203, 112506

[17] Thanikachalam, P. V.; Maurya, R. K.; Garg, V.; Monga, V. Eur. J. Med. Chem. 2019, 180, 562.

[18] Scuto, A.; Kirschbaum, M.; Kowolik, C.; Kretzner, L.; Juhasz, A.; Atadja, P.; Pullarkat, V.; Bhatia, R.; Forman, S.; Yen, Y.; Jove, R. Blood 2008, 111, 5093.

[19] Cross, D.; Ashton, S.; Nebhan, C.; Eberlein, C.; Finlay, M. R. V.; Hughes, G.; Jacobs, V.; Mellor, M.; Red Brewer, M.; Meador, C.; Orme, J.; Spitzler, P.; Powell, S.; Rahi, A.; Taylor, P.; Ward, R. A.; Daunt, P.; Galer, A.; Klinowska, T.; Richmond, G.; Pao, W. Mol. Cancer Ther. 2013, 12, A109.

[20] Fu, D. J.; Cui, X. X.; Zhu, T.; Zhang, Y. B.; Hu, Y. Y.; Zhang, L. R.; Wang, S. H.; Zhang, S. Y. Bioorg. Chem. 2021, 107, 104634.

[21] Li, W.; Shuai, W.; Sun, H.; Xu, F.; Bi, Y.; Xu, J.; Ma, C.; Yao, H.; Zhu, Z.; Xu, S. Eur. J. Med. Chem. 2019, 163, 428.

[22] Guo, T.; Liu, Y.; Zhao, Y. H.; Zhang, P. K.; Han, S. L.; Liu, H. M. Tetrahedron Lett. 2016, 57, 4629

[23] Hu, Y.; Li, Z.-Y.; Ding, Y.-J.; Li, Z.-Y.; Liu, Z.-Y.; Shen, Y.-M. Chin. J. Org. Chem. 2019, 39, 3230 (in Chinese). (胡园, 李震宇, 丁艳娇, 李志颖, 刘志勇, 沈月毛, 有机化学, 2019, 39, 3230.)

[24] Yuan, S.; Yu, B.; Liu, H. M. Adv. Synth. Catal. 2018, 361, 59.

[25] Jian, S.; Gao, Q.-L.; Wu, B.-W.; Li, D.; Shi, L.; Zhu, T.; Lou, J.-F.; Jin, C.-Y.; Zhang, Y.-B.; Zhang, S.-Y.; Liu, H.-M. Eur. J. Med. Chem. 2019, 183, 111731 . 